\title{
Malaysian limestone orchids status: diversity, threat and conservation
}

\author{
G. Rusea ${ }^{1}$, M.Y.L. Lim ${ }^{1}$, S.N. Phoon ${ }^{2}$, W.S.Y. Yong ${ }^{2}$, C.H. Tang ${ }^{1}$, H.E. Khor ${ }^{1}$, \\ J.O. Abdullah ${ }^{1}$, J. Abdullah ${ }^{3}$
}

Key words

conservation

diversity

limestone orchids

Malaysian

threat

\begin{abstract}
To date, a total of 288 species from 96 genera were identified from the limestone areas in Perlis and Padawan-Bau, Sarawak, of which many of these are restricted to limestone habitat and either endemic to Perlis or to Sarawak. Knowledge and data obtained from the field observation over the past 8 years leads us to report that at least 15 species endemic to limestone has become rare in the wild in Perlis, Bau and Padawan Sarawak. This was mainly attributed by: i) lack of emphasis by the government on understanding and protecting biodiversity in this kind of habitat; ii) lack of scientists willing to do research in dangerous and disaster prone limestone habitat; and iii) lack of knowledge and awareness among local communities on the importance of conserving and utilizing their natural resources in a sustainable manner.
\end{abstract}

Published on 30 October 2009

\section{INTRODUCTION}

Orchids are the largest flowering plant family in Malaysia (including Sabah and Sarawak) with about 2000 species, of which 700 are recorded from limestone. Threats to orchids on limestone include small-scale logging (extracting timber by the locals for building materials), quarrying, land clearance for traditional farming, and collecting for trade, especially of genera such as Paphiopedilum and Phalaenopsis. International legal protection is provided by the Convention on International Trade in Endangered Species of Wild Fauna and Flora (CITES), Convention on Biological Diversity (CBD), national legislation by the Forest Ordinance 1954, Wildlife Protection Ordinance 1990, Wildlife Enactment 1997, Wild Life Protection Ordinance 1998 (Sarawak).

Two major limestone hills areas of Malaysia were identified for orchid diversity study, located in Perlis and Sarawak.

Perlis $\left(6^{\circ} 15^{\prime} \mathrm{N}, 100^{\circ} 6^{\prime}\right.$ to $\left.100^{\circ} 23^{\prime} \mathrm{E}\right)$ is the smallest northernmost state in Peninsular Malaysia. It has two monsoons: warm and dry $\left(23-36{ }^{\circ} \mathrm{C}\right)$ from January to April, and wet and slightly cooler $\left(23-32^{\circ} \mathrm{C}\right)$ from September to December. The average annual rainfall is $1735 \mathrm{~mm}$. The rainfall peak is in October and the lowest in April-May (Meteorology Department Malaysia, years 2002-2004). In age, the Perlis limestones range from Cambrian to late Triassic (Jasin \& Harun 2002).

Padawan is in the Kuching district, Sarawak, Borneo (1 $1^{\circ} 10^{\prime} \mathrm{N}$ $\left.110^{\circ} 16^{\prime} \mathrm{E}\right)$. It has a hot and humid climate throughout the year, with temperatures of $23.1-31.6^{\circ} \mathrm{C}$, and an average annual rainfall of $4090 \mathrm{~mm}$ (Malaysian Meteorological Service Database 2002, Mineral and Geoscience Department Database 2002). In age, the Padawan limestones range from Upper Jurassic to Upper Cretaceous (Wilford 1965)

\section{MATERIAL AND METHODS}

In both areas limestone hills and some adjacent landscape features were selected for this survey (Table 1). In Sarawak, two rivers were included that flow through the limestone hills and valleys. In Perlis Gunung Perlis was included in full, as there is no distinct boundary between the limestone and granite parts that form the mountain.

This study is based on material in KEP, KLU, SAR, SING and UKMB, as well as from field observations. Identification down to species level of most material was possible, because the orchid flora of Peninsular Malaysia is described in three subsequent accounts: Ridley (1924), Holttum (1964), Seidenfaden \& Wood (1992). The exploration of the Borneo orchids is less far advanced. Only checklists have been published: Ridley (1896), Masamune (1942) and Beaman et al. (2001). The following have also been used for identification: Dressler (1981), Comber (1990, 2001), Vermeulen (1991), Pridgeon (1992), Chan et al.

Table 1 List of sites visited in both areas

\begin{tabular}{ll}
\hline Perlis & Padawan \\
\hline Bukit Bintang & Gunung Baju \\
Bukit Chabang & Gunung Bangan \\
Bukit Genting Hantu & Gunung Batu Putih \\
Bukit Gua Ikan & Gunung Bekap \\
Bukit Mata Ayer & Gunung Bewang \\
Bukit Merah & Gunung Braang \\
Bukit Rongkit & Gunung Ganjing \\
Bukit Teluk Tapu & Gunung Gayu \\
Bukit Wang Pisang & Gunung Mangan \\
Bukit Wang Mu & Gunung Manok \\
Gunung Perlis (granite) & Gunung Mentawa \\
& Gunung Mesih \\
& Gunung Papak \\
& Gunung Regu \\
& Gunung Rinu \\
& Gunung Serrad \\
& Gunung Timungan \\
& Gunung Timurang \\
& Gunung Tuang \\
& Sungai Abang (a river) \\
& Sungai Serin (a river) \\
\hline
\end{tabular}

\footnotetext{
1 Biology Department, Faculty of Science, Universiti Putra Malaysia, 43400 Serdang, Selangor, Malaysia.

2 Forest Research Institute of Malaysia (FRIM), 52109 Kepong, Selangor, Malaysia.

${ }^{3}$ Forest Research Centre, Sarawak Forest Corporation, Kuching, Sarawak.
} 
Table 2 List of orchid species collected from Perlis Limestone Area.

Taxa

\begin{tabular}{|c|c|c|c|c|c|c|c|c|c|c|c|}
\hline 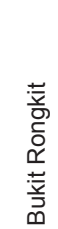 & 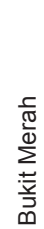 & 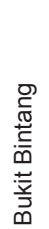 & 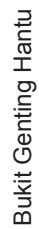 & 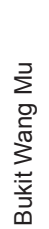 & 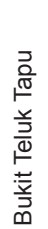 & 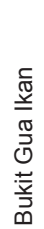 & 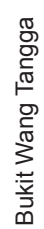 & 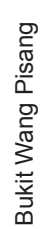 & 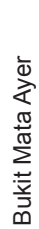 & 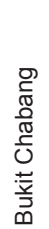 & $\begin{array}{l}\text { on } \\
\bar{D} \\
0 \\
0 \\
\subseteq \\
5 \\
5 \\
0\end{array}$ \\
\hline
\end{tabular}

Acampe rigida

Aerides odorata.

Agrostophyllum $\mathrm{sp}$.

Apotasia nuda

Ascocentrum miniatum

Ascocentrum sp.

Biermannia ciliata

Bulbophyllum dentiferum

Bulbophyllum lilacinum

Bulbopyhllum microglossum

Bulbophyllum mutabile

Bulbophyllum purpurascens

Bulbophyllum taeniophyllum

Bulbophyllum sp. 1

Bulbophyllum sp. 2

Calanthe sp.

Ceratostylis radiata

Ceratostylis subulata

Chamaeanthus sp.

Cleisostoma discolor

Cleisostoma subulatum

Cleisostoma williamsonii

Coelogyne trinervis

Coelogyne sp. 1

Coelogyne sp. 2

Coelogyne sp. 3

Cymbidium aloifolium

Cymbidium ensifolium ssp. haematodes

Cymbidium lancifolium

Cymbidium sp. 1

Dendrobium acerosum

Dendrobium aloifolium

Dendrobium anosmum

Dendrobium concinnum

Dendrobium crumenatum

Dendrobium hughii

Dendrobium indivisum

Dendrobium indivisum var. pallidum

Dendrobium kentrophyllum

Dendrobium leonis

Dendrobium linguella

Dendrobium salaccense

Dendrobium secundum

Dendrobium setifolium

Dendrobium trinervium

Dendrobium truncatum

Dienia ophrydis

Eria densa

Eria floribunda

Eria javanica

Eria mucronata

Eria nutans

Eria ochracea

Eria ornata

Eria tenuiflora

Eria sp.

Eulophia andamanensis

Flickingeria angustifolia

Flickingeria bancana

Flickingeria convexa

Flickingeria fimbriata

Flickingeria pallens

Flickingeria xantholeuca

Flickingeria sp. 1

Flickingeria sp. 2

Flickingeria sp. 3

Flickingeria sp. 4

Flickingeria sp. 5

Gastrochilus hainanensis

$\begin{array}{llll} & + & \\ + & + & +\end{array}$

Gastrodia javanica

Grosourdya incurvicalar

Grosourdya muscosa 
Table 2 (cont.)

\begin{tabular}{|c|c|c|c|c|c|c|c|c|c|c|c|c|}
\hline Taxa & 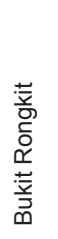 & 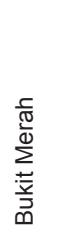 & 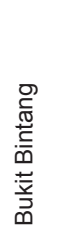 & 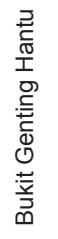 & 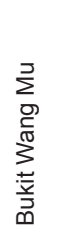 & 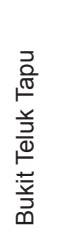 & 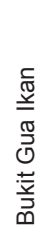 & 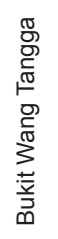 & 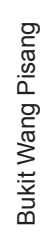 & 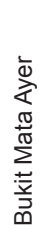 & 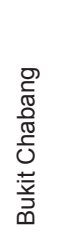 & 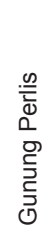 \\
\hline Habenaria carnea & + & + & + & & & & & & + & & & \\
\hline Habenaria reflexa & & & & + & & & & & + & & & \\
\hline Kingidium deliciosum & + & + & + & + & & & + & & + & & & \\
\hline Liparis aurita & & & & & & & & & + & & & \\
\hline Liparis cespitosa & & & & & & & & & & & & + \\
\hline Liparis viridiflora & & + & & & & & & & & & & \\
\hline Luisia sp. & + & & & & & & & & & & & \\
\hline Macodes petola & & & & & & & & & & & & + \\
\hline Malaxis calophylla & & & & & & & & & + & & & \\
\hline Malaxis prasina & & & & & & & & & + & & & \\
\hline Malaxis sp. 1 & & & & & & & & & + & & & \\
\hline Malaxis sp. 2 & & & & & & & & & + & & & \\
\hline Malaxis sp. 3 & & & & & & & & & & & & + \\
\hline Nephelaphyllum pulchrum & & & & & & & & & & & & + \\
\hline Nervilia plicata & & & & + & & & & & + & & & \\
\hline Nervilia punctata & & & & & & & & & + & & & \\
\hline Oberonia ensiformis & & + & & & & & & & & & & \\
\hline Oberonia langbianensis & + & & & & & & & & & & & \\
\hline Oberonia sp. & & + & & & & & & & & & & \\
\hline Panisea uniflora & & & & & & & & & + & & & \\
\hline Paphiopedilum niveum & + & + & + & & & & & & & & & \\
\hline Pennilabium struthio & & & & & & & & & + & & & \\
\hline Pholidota imbricata & + & + & & & & + & & & + & & & + \\
\hline Pholidota recurva & & & & & & & & & & & & + \\
\hline Pholidota sp. & + & & & & & & & & & & & \\
\hline Podochilus lucescens & + & + & + & + & + & & & & + & & & \\
\hline Polystachya concreta & + & & & & & & & & & & & \\
\hline Pomatocalpa andamanica & + & + & & & + & + & & & + & & & \\
\hline Pomatocalpa spicata & & & & & + & & & & + & + & & \\
\hline Porpax sp. & & & & & & & & & + & & & \\
\hline Renanthera sp. & & & & & & & & & & & & + \\
\hline Renantherella histrionica & + & + & & + & & & & & & & & \\
\hline Spathoglottis plicata & & & & & + & & & & & & & \\
\hline Stereosandra javanica & & & & & & & & & & & & + \\
\hline Taeniophyllum intermedium & & & & & & & & & & & & + \\
\hline Tainia speciosa & & & & & & & & & & & & + \\
\hline Thelasis pygmae & & + & + & & & & & & + & & & \\
\hline Thelasis rhomboglossa & + & & & & & & & & & & & \\
\hline Thrixspermum pensile & & & & & & & & & & & & + \\
\hline Trichoglottis bipunctata & & & & + & + & & + & & & & & \\
\hline Trichoglottis cirrhifera & + & + & & & + & + & + & & & & & \\
\hline Trichotosia gracilis & & & & & & & & & & & & + \\
\hline Tropidia curculigoides & + & & & + & & & & & & & & \\
\hline Tropidia sp. & & + & & & & & & & & & & \\
\hline Tuberolabium sp. & + & & & & & & & & & & & \\
\hline Total number of taxa & 36 & 30 & 10 & 17 & 11 & 10 & 7 & 4 & 1 & 1 & 1 & 35 \\
\hline
\end{tabular}

(1994), Wood \& Cribb (1994), Turner (1995), Wood (1997, 2001), Julaihi (2001), Rusea et al. (2001). Wherever possible, type specimens, or images of types, were consulted from $\mathrm{K}$, KEP, KLU, L, SAR, SING, UKMB.

\section{RESULTS AND DISCUSSIONS}

A total of 288 taxa in 96 genera were recorded, 117 from Perlis (Table 2) and 188 from Padawan (Table 3). Bulbophyllum reticulatum, Cleisostoma discolor, Dendrobium truncatum, Dossinia marmorata, Eulophia andamanica, Habenaria carnea, Malaxis prasina, Paphiopedilum stonei, Phalaenopsis bellina and Pomatocalpa andamica are endemic to limestone. Bulbophyllum reticulatum, Paphiopedilum stonei and Phalaenopsis bellina are endemic to Sarawak. Habenaria carnea, Malaxis prasina, Paphiopedilum niveum and Pomatocalpa andamanica are endemic to the limestone area extending from southern Thailand to Langkawi island, and including Perlis. Phalaenopsis coch- learis was categorized as Critically Endangered; Bulbophyllum reticulatum, Paphiopedilum stonei and Vanda scandens as Endangered (1997 and 2006 IUCN Red List criteria).

As for the Padawan limestones, a $3.1 \mathrm{~km}^{2}$ area harboured $18 \%$ of the total Sarawak orchids species and $40 \%$ of the genera. In Perlis, a $0.96 \mathrm{~km}^{2}$ plot harbours $12.3 \%$ of the total Peninsular Malaysian orchid species and $35.0 \%$ of the genera. This remarkable diversity is more difficult to explain. We suggest a varied topography and geology, and favourable climatic conditions would offer the best explanations. The number of new records in both areas is remarkably high. In Perlis a total of 62 species were identified as new records (Table 4) whilst Padawan has 73 species (Table 5).

The high number of new records in both areas can be attributed to insufficient collecting in the past. Indeed, the orchid flora of both areas studied is poorly represented in herbaria.

Increasingly, illegal collecting is a problem in both areas. On a large scale, plants are collected to be exported for sale to orchid 
Table 3 List of orchid species collected from Padawan Limestone Area.

Taxa

\begin{tabular}{|c|c|c|c|c|c|c|c|c|c|c|c|c|c|c|c|c|c|c|c|}
\hline 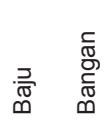 & 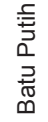 & $\begin{array}{l}\frac{Q}{\mathbb{\varpi}} \\
\frac{v}{\Phi} \\
\infty\end{array}$ & $\begin{array}{l}\text { D) } \\
\text { (1) } \\
\sum_{0} \\
\infty\end{array}$ & $\begin{array}{l}\text { D } \\
\frac{\pi}{\mathbb{N}} \\
\frac{\pi}{2} \\
\bar{n}\end{array}$ & 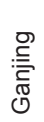 & 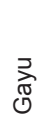 & 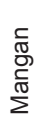 & 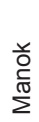 & 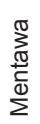 & $\begin{array}{l}\frac{c}{5} \\
\frac{\mathbb{E}}{\Sigma}\end{array}$ & 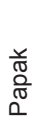 & 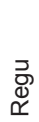 & 旁 & 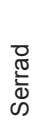 & 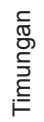 & 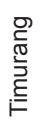 & 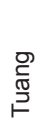 & 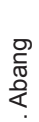 & 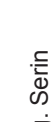 \\
\hline ن் & ن் & ம் & ن் & ن் & ن் & ن் & ن் & ن் & ம் & ن் & ن் & ن் & ن் & ن் & ம் & ०) & ن் & க) & \\
\hline
\end{tabular}

Abdominea minimiflora

Acanthephippium sp.

Acriopsis liliifolia

Agrostophyllum bicuspidatum

Agrostophyllum longifolium

Agrostophyllum majus

Agrostophyllum sumatranum

Agrostophyllum sp.

Appendicula anceps

Appendicula cornuta

Appendicula pendula

Appendicula purpurascens

Appendicula ramosa

Appendicula undulata

Appendicula sp. 1

Appendicula sp. 2

Appendicula sp. 3

Arundina graminifolia

Biermannia sp.

Brachypeza indusiata

Bromheadia finlaysoniana

Bulbophyllum acuminatum

Bulbophyllum apodum

Bulbophyllum armeniacum

Bulbophyllum blumei

Bulbophyllum botryophorum

Bulbophyllum compressum

Bulbophyllum coniferum

Bulbophyllum flammuliferum

Bulbophyllum flavescens

Bulbophyllum gracillimum

Bulbophyllum longiflorum

Bulbophyllum purpurascens

Bulbophyllum reticulatum

Bulbophyllum tortuosum

Bulbophyllum vaginatum

Bulbophyllum vermiculare

Bulbophyllum sp. 1 sect. Aphanobulbon

Bulbophyllum sp. 2

Bulbophyllum sp. 3

Bulbophyllum sp. 4

Bulbophyllum sp. 5

Bulbophyllum sp. 6

Bulbophyllum sp. 7

Bulbophyllum sp. 8

Calanthe sp.

Cleisostoma discolor

Cleisostoma nieuwenhuisi

Cleisostoma striatum

Cleisostoma subulatum

Cleisostoma sp. 1

Cleisostoma sp. 2

Coelogyne asperata

Coelogyne dayana

Coelogyne incrassata

Coelogyne mayeriana

Coelogyne prasina

Coelogyne rochussenii

Coelogyne sanderiana

Coelogyne swaniana

Coelogyne sp. 1

Coelogyne sp. 2

Coelogyne sp. 3

Coelogyne sp. 4

Coelogyne sp. 5

Coelogyne sp. 6

Corybas pictus

Corymborkis veratrifolia

Cymbidium finlaysonianum

$\begin{array}{rrr}+ & & \\ + & + & \\ + & + \\ + & +\end{array}$

$+$

Cymbidium rectum

Cymbidium sp. 1

Cymbidium sp. 2

Dendrobium acinaforme

Dendrobium anosmum

Dendrobium clavator 
Table 3 (cont.)

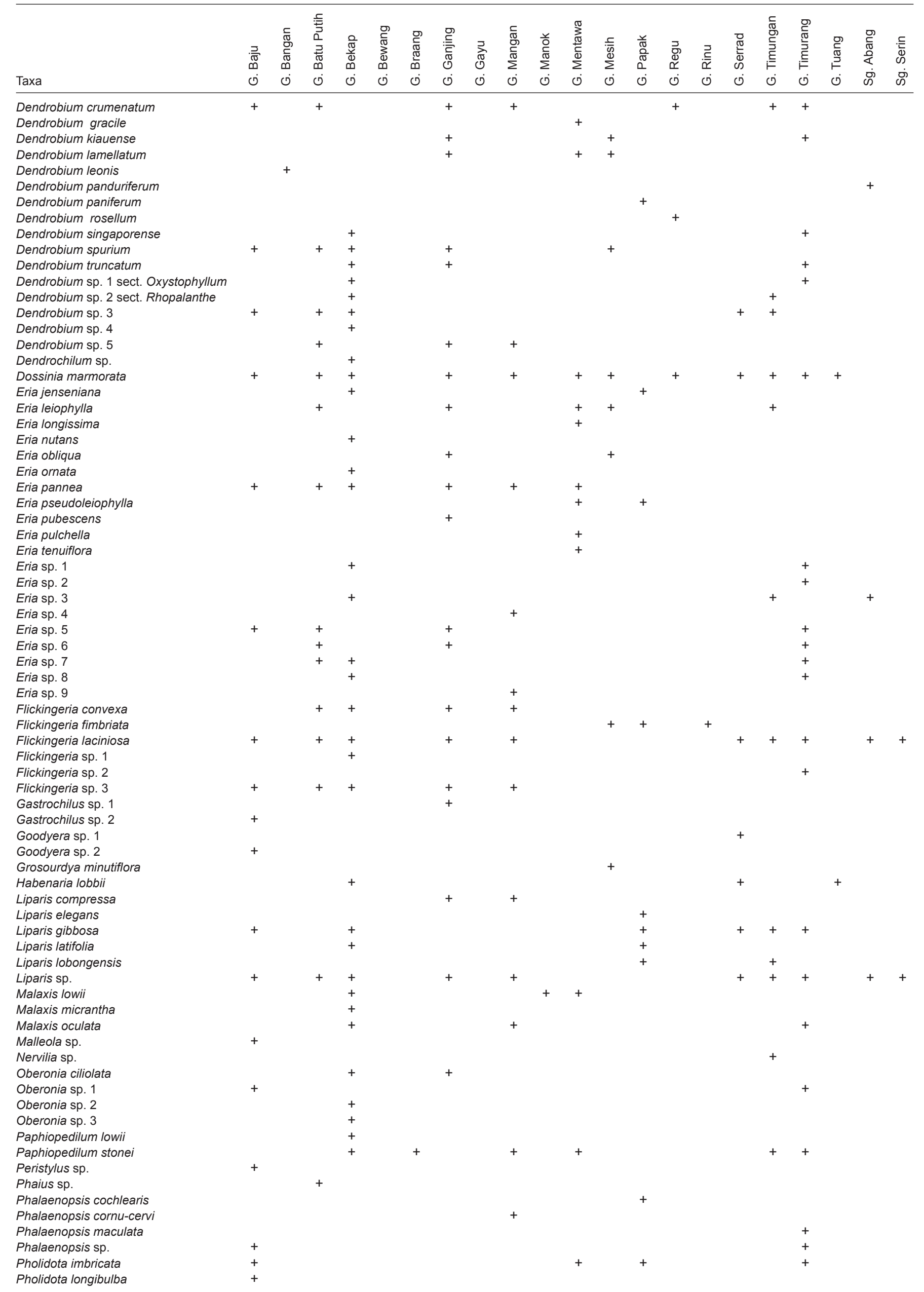


Table 3 (cont.)

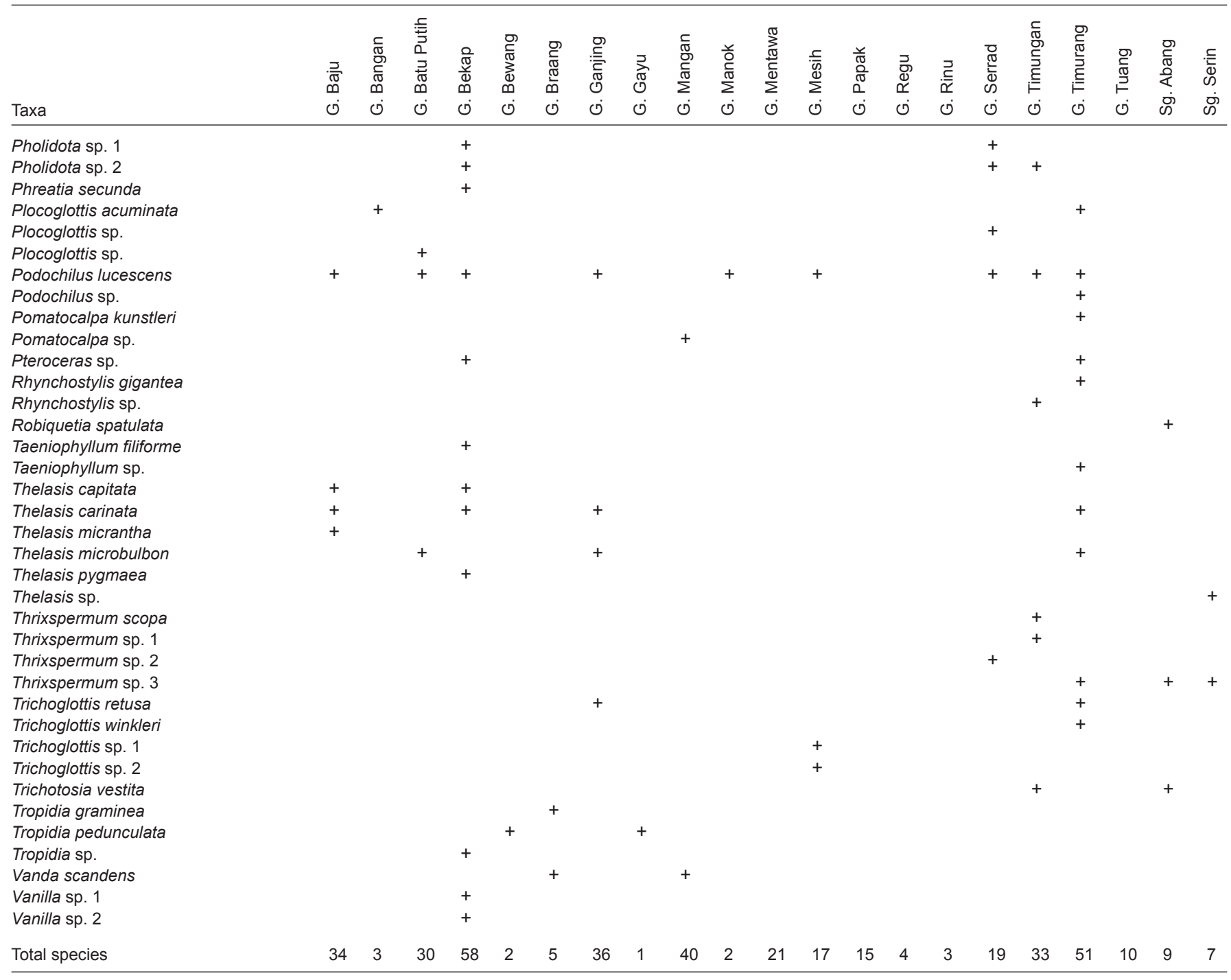

amateurs. Collecting for use as stock material for the orchid hybrid industry is only a problem in very few species. Collecting is very efficiently done by locals with detailed knowledge of the area visited. Nurseries then buy the plants and arrange the exports to the US, Japan and Europe. Species severely threatened this way are Bulbophyllum reticulatum, Dossinia marmorata, Paphiopedilum stonei and Phalaenopsis.

Forest clearing for logging and development takes 760-900 $\mathrm{km}^{2} /$ year in Peninsular Malaysia alone (Davis et al. 1986). It destroys orchid habitats on the short run, but it also changes the climate on the longer run. Shade loving ground flora (Kiew 1993) as well as the less hardy epiphytes will disappear.

In Sarawak, about $23 \%$ of the total land area is under shifting cultivation (Kiew 1993). Among locals it is common practice to clear forest yearly for this purpose (Anonymous 1983). In Padawan, land clearance for various crops is not restricted to the foot of the hills, but may extend to the top. An additional risk is that the fire used to clear the land sweeps through the surrounding vegetation, destroying even more habitat.

Little rock quarrying is done in Padawan, yet this is a potential threat because of the increasing demand of stone and, in particular, cement. In nearby Bau quarrying is relatively well regulated and therefore has mainly a local effect. Nevertheless, it may threaten limestone species with a limited range, such as Bulbophyllum reticulatum and Paphiopedilum stonei.

Altogether, 15 limestone endemic orchids have become rare in Perlis and Padawan. More research in limestone areas is needed to curb this trend, in spite of the notoriously difficult access to these deeply dissected, very steep limestone hills with their often knife-sharp rock outcrops. Awareness of the extraordinary biodiversity among the local communities should be fostered.

\section{CONCLUSION AND RECOMMENDATION}

The orchid diversity in both areas is very high, and conservation measures are necessary to ensure long-term survival. In situ and ex situ options are available.

In situ conservation is to be preferred because it preserves not species but ecosystems.

Unfortunately, the awareness of the need to protect nature in general and orchids in particular, is still low among Malaysians (WWF 2000). Besides, taxonomic knowledge of the local biodiversity is still inadequate. Local universities and research institutions need encouragement to generate this awareness among their students. The deficiency of taxonomic information also prevents Malaysia from using these resources for biotechnology (The New Straits Times, 11 Sept. 2002, p. 8).

Ex situ conservation could include propagation of species via tissue culture or seed. Rare and endangered limestone species such as Bulbophyllum reticulatum, Paphiopedilum stonei, Vanda scandens as well as Phalaenopsis could benefit from this. The wild populations could be replenished and the commercial market could be saturated, relieving the pressure on 
Table 4 List of new records for Perlis.

\begin{tabular}{|c|c|c|c|}
\hline No. & Species & No. & Species \\
\hline 1. & Acampe rigida (Buch.-Ham. ex Sm.) P.F.Hunt & 32. & Flickingeria xantholeuca (Rchb.f.) Hawkes \\
\hline 2. & Apotasia nuda R.Br. & 33. & 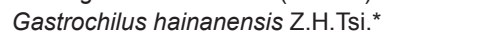 \\
\hline 3. & Biermannia ciliata (Ridl.) Garay & 34. & Gastrodia javanica (Blume) Lindl. \\
\hline 4. & Bulbopyhllum microglossum Ridl. & 35. & Grosourdya incurvicalar (J.J.Sm.) Garay \\
\hline 5. & Bulbophyllum mutabile (Blume) Lindl. & 36. & Grosourdya muscosa (Rolfe) Garay \\
\hline 6. & Bulbophyllum purpurascens Teijsm. \& Binn. & 37. & Habenaria reflexa Blume \\
\hline 7. & Ceratostylis radiata J.J.Sm. & 38. & Kingidium deliciosum (Rchb.f.) Sweet \\
\hline 9. & Cirrhopetalum taeniophyllum (C.S.P.Parish \& Rchb.f.) Hook.f. & 40. & Liparis cespitosa (Lam.) Lindl. \\
\hline 10. & Cleisostoma subulatum Blume & 41. & Liparis viridiflora (Blume) Lindl. \\
\hline 11. & Coelogyne trinervis Lindl. & 42. & Macodes petola (Blume) Lindl. \\
\hline 12. & Cymbidium ensifolium (L.) Sw. & 43. & Malaxis calophylla (Rchb.f.) Kuntze \\
\hline 13. & Dendrobium acerosum Lindl. & 44. & Nephelaphyllum pulchrum Blume \\
\hline 14. & Dendrobium concinnum Miq. & 45. & Nervilia punctata (Blume) Makino \\
\hline 15. & Dendrobium hughii Rchb.f. & 46. & Oberonia ensiformis (J.J.Sm.) Lindl.* \\
\hline 16. & Dendrobium indivisum (Blume) Miq. & 47. & Oberonia langbianensis Gagnep.* \\
\hline 17. & Dendrobium indivisum (Blume) Miq. var pallidum Seidenf. & 48. & Panisea uniflora Lindl.* \\
\hline 19. & Dendrobium setifolium Ridl. & 50. & Pholidota imbricata Hook. \\
\hline 20. & Dendrobium truncatum Lindl. & 51. & Pholidota recurva Lindl.* \\
\hline 21. & Dienia ophrydis (J.König) Ormerod \& Seindenf. & 52. & Polystachya flavescens (Blume) J.J.Sm. \\
\hline 22. & Eria densa Ridl. & 53. & Pomatocalpa andamanica (Hook.f.) J.J.Sm. \\
\hline 23. & Eria floribunda Lindl. & 54. & Spathoglottis plicata Blume \\
\hline 24. & Eria javanica (Sw.) Blume & 55. & Stereosandra javanica Blume \\
\hline 25. & Eria mucronata Lindl. & 56. & Taeniophyllum intermedium Carr \\
\hline 26. & Eria nutans Lindl. & 57. & Tainia speciosa Blume \\
\hline 27. & Eria ochracea Rolfe* & 58. & Thelasis pygmae (Griff.) Blume \\
\hline 28. & Eria tenuiflora Ridl. & 59. & Thelasis rhomboglossa Kraenzl. ${ }^{*}$ \\
\hline 29. & Flickingeria angustifolia (Blume) A.D.Hawkes & 60. & Thrixspermum pensile Schltr.* \\
\hline & Flickingeria bancana (J.J.Sm.) A.D.Hawkes & 61. & Trichotosia gracilis (Hook.f.) Kraenzl. \\
\hline 31. & Flickingeria convexa (Blume) A.D.Hawkes & 62. & Tropidia curculigoides Lindl. \\
\hline
\end{tabular}

* New records for Malaysia.

Table 5 List of new records of species for Padawan, Sarawak.

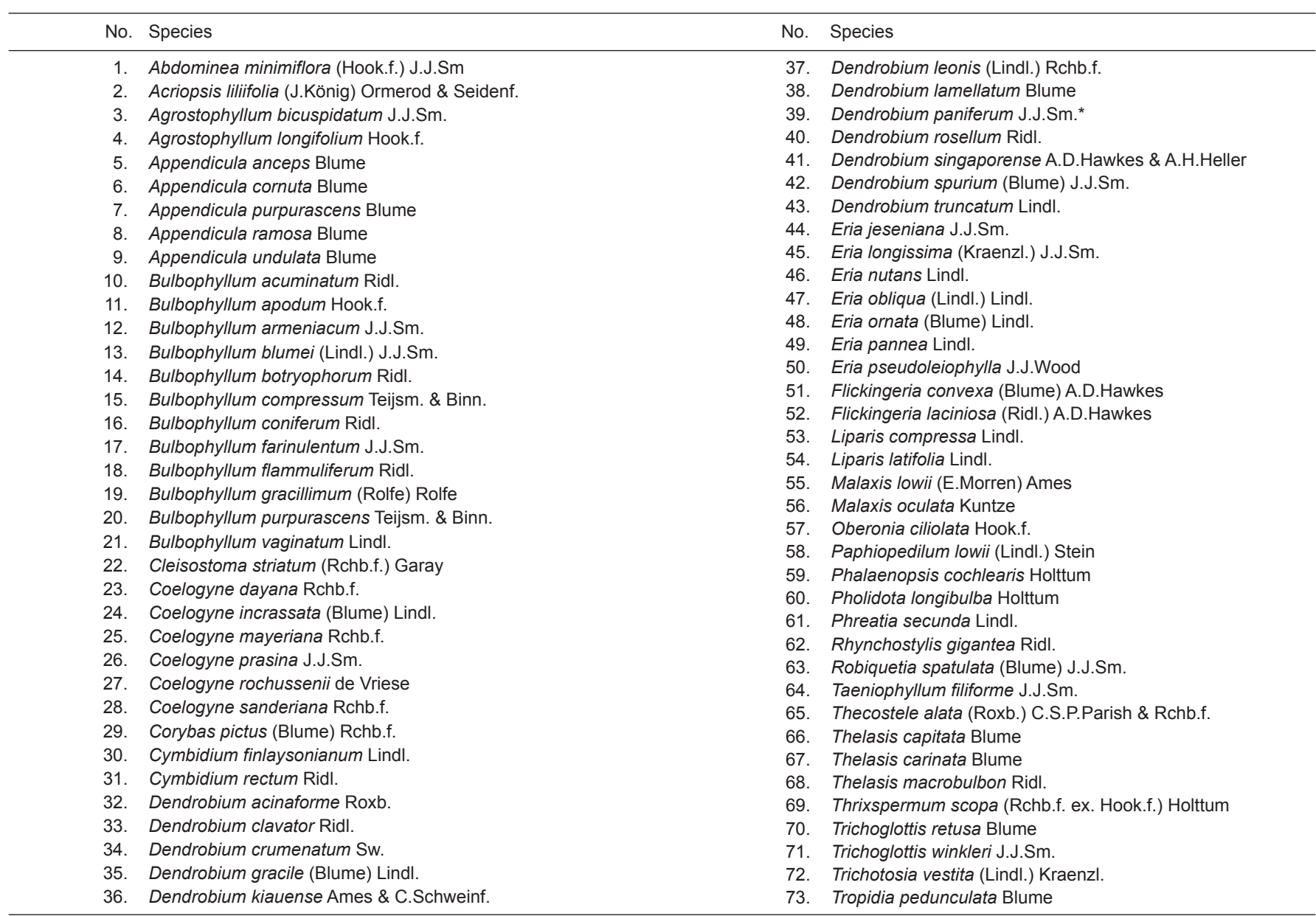


the wild populations. Other attractive Padawan orchids, such as Dendrobium anosmum (both white and purple form), Dossinia marmorata, and Plocoglottis acuminata can be recommended in this respect.

Apart from the above, further enforcement of international and local laws, listed above, is advisable to ensure that limestone biodiversity is preserved for future generations.

Acknowledgements The authors would like to thank the Ministry of Science and Innovation for funding this project under IRPA RM8 no. 08-0204-0249-EA001. We would like to thank the Perlis Forestry Department and the Sarawak Forestry Department for providing accommodation and assistance during fieldwork.

\section{REFERENCES}

Anonymous. 1983. Department of Agriculture Sarawak Annual Report. Department of Agriculture, Sarawak.

Beaman TE, Wood JJ, Beaman RS, Beaman JH. 2001. Orchids of Sarawak. Natural History Publications (Borneo).

Chan CL, Lamb A, Shim PS, Wood JJ. 1994. Orchids of Borneo Vol. 1. The Sabah Society, Kota Kinabalu and The Royal Botanic Gardens, Kew.

Comber JB. 1990. Orchids of Java. Bentham-Moxon Trust, Royal Botanic Garden, Kew.

Comber JB. 2001. Orchids of Sumatra. Natural History Publications (Borneo), Kota Kinabalu and The Royal Botanic Gardens, Kew.

Davis SD, Droop SJM, Gregerson P, Henson L, Leon CJ, Villa-Labos JL, Synge H, Zantovxka J. 1986. Plants in danger: What do we know? IUCN, Gland, Switzerland.

Dressler RL. 1981. The orchids natural history and classification. Harvard University Press, Cambridge.

Holttum RE. 1964. A revised Flora of Malaya. Vol. 1. Orchids of Malaya. Government Printing Office, Singapore.

IUCN. 1997. 1997 IUCN Red list of threatened plants. http://www.iucn.org Accessed on 20 May 2005.

IUCN. 2006. List of the globally threatened orchids' species http://www.iucn. org. Accessed on 15 August 2006.
Jasin B, Harun Z. 2002. Geomorphology and geology of the Setul Formation in Perlis. In: Faridah I-Hanum, Osman K, Yussof AR, Latiff A (eds), Biodiversity and management of Perlis State Park (Physical, biological and social environments of Wang Mu): 68-82. Forest Department of Perlis, Kangar, Perlis, Malaysia.

Julaihi A. 2001. Wild orchids in Sarawak - diversity and conservation. In Persidangan Perhutanan Malaysia Ke 13: 1-16. Johor Bahru, Jabatan Perhutanan Semenanjung Malaysia.

Kiew R. 1993. A flora survey of limestone hills in Perlis (Project No. 272/93). In: Sharma DSK, Mathew D, Lim SH (eds), Management recommendations for the establishment of a Perlis State Park: iv-4. WWF, Malaysia.

Masamune G. 1942. Enumeratio Phanerogamarum Bornearum. Government Printing Office, Taiwan.

Pridgeon A. 1992. Orchids of the world. Weldon Publishing, Sydney.

Ridley HN. 1896. An enumeration of all Orchidaceae hitherto recorded from Borneo. Journal of the Linnean Society, Botany 31: 261-305.

Ridley HN. 1924. Flora of the Malay Peninsula. Vol. 4: 100-221. Reeves, London.

Rusea G, Bibian MD, Julaihi A. 2001. Orchids from Bau conserved at Semenggoh, Sarawak. Folia Malaysiana 2, 4: 277-282.

Seidenfaden G, Wood J. 1992. The orchids of Peninsular Malaysia and Singapore. The Royal Botanic Gardens Kew, Botanic Gardens Singapore and Olsen, Olsen, Denmark.

The New Straits Times. 11 September 2002: 8

Turner IM. 1995. A catalogue of the vascular plants of Malaya Orchidaceae. Garden's Bulletin Singapore 47: 559-620.

Vermeulen JJ. 1991. Orchids of Borneo, Vol. 2: Bulbophyllum. Royal Botanic Gardens, Kew and Toihaan Publishing Company Sdn. Bhd., Kota Kinabalu.

Wilford GE. 1965. Geological Survey, Borneo Region, Malaysia, Report 2, Penrissen Area, West Sarawak, Malaysia. Explanation of Sheets 0-110-2, 1-110-13 and 1-110-14. Geoscience and Mineral Department, Malaysia.

Wood JJ. 1997. Orchids of Borneo Vol. 3: Dendrobium, Dendrochilum and others. The Sabah Society Kota Kinabalu and The Royal Botanic Gardens, Kew.

Wood JJ. 2001. Dendrochilum of Borneo. Natural History Publications (Borneo), Kota Kinabalu.

Wood JJ, Cribb PJ. 1994. A checklist of the Orchids of Borneo. Royal Botanic Gardens, Kew.

WWF. 2000. Workshop report on conservation of wild orchids in Sabah. Sabah, Malaysia. 